\title{
A Study for Determining the Brand Personality of Kyrenia City: North Cyprus
}

\author{
Nimet Harmanci \\ Faculty of Communication \\ Girne American University, Girne, Turkey
}

\begin{abstract}
Personality traits can be attributed to products, services, or destinations since the personality traits unique to human beings are also transferable to objects. Having personality traits, which are one of the essential elements of being a brand, is primarily the result of an uncontrolled and unconscious process that develops spontaneously. However, one of the first steps to be taken by a destination that wants to become a brand is to have a well-thought and planned personality. Personality traits, which mainly occur spontaneously and randomly, form the basis of the interaction between humans and objects. This study, which focuses on Kyrenia city's brand city personality, aims to investigate the attitudes of the internal and external stakeholders of the brand personality towards their cities. Within the scope of the research, in order to measure the brand personality of the Kyrenia region, the brand personality scale adapted from J. L Aaker's (1997) brand personality scale was used with five dimensions, 15 sub-dimensions, and 39 items, and data results were collected over 394 people in total. As a result of the analysis, the brand personality scale has been gathered under five main factors. These; It is grouped as Sincerity, Excitement, Competence, Sophistication, Ruggedness. According to the results obtained from this study, in which personality suggestions about the city of Kyrenia, which is considered as a sample, the brand personality of the city of Kyrenia is presented; has young, contemporary/modern, independent, up-to-date, upper-class, goodlooking and attractive personality traits.
\end{abstract}

Keywords: Brand Personality, Brand Personality Scale, City, Kyrenia, North Cyprus

Corresponding author: Nimet Harmanci; E-mail: nimetharmanci@gau.edu.tr DOI: https://doi.org/10.37227/ITHJ-2021-05-1093

\section{Introduction}

The social, cultural, and physical environment is one of the most important factors affecting human beings' material and spiritual development. There is such an interaction between man and the city surrounding him; Every change, positive or negative, is reflected on the human being and the person's experiences on the environment and the city. Thus; The city and the people are mutually influential in each other's past, daily life, future, happiness, sadness, and eventual destiny. Like human beings, cities also have a soul, identity, and personality.

In recent years, many studies have been carried out on the brand concept, which expresses the value (Aksoy, 2005: 40) that is mainly built in the minds of consumers. Especially the development of tourism and the increase in the value created by cities for countries' economies 
have caused many institutional structures such as sports clubs (Ustakara and Aydemir, 2016: 16) or destinations to focus on branding issues other than product and service producers. However, in order for the brand to consist of cultural ideas with strategic value (Grant, 2006: 55) to emerge, it must have a personality as well as many elements such as identity, a unique promise, name, associative elements, and positioning.

The meanings produced by the personality (Taşkin and Akat, 2008: 104), which is a concept related to a person's social reputation and inner nature, enables the integration with the brand and makes it an element for the brand. The brand produces various meanings with its personality traits and can transfer these meanings to consumers. Therefore, to create a practical brand value in cities struggling with branding, they must first acquire a well-planned brand personality.

Each city has its unique characteristics with its historical accumulations, the influence of its geography, and its social, cultural, and commercial history (Gelibolu et al., 2014: 24). Today's cities, where global competition is intense, are becoming a more preferred city for investors, visitors, and residents. Therefore, city brand personality is an indispensable element of a city; a more assertive city brand personality creates an attractive city brand (Ahmad, Ezhar, Bolong, 2013: 34). Hence, the perceived upbeat personality of a city; contributes to people gaining a competitive advantage by influencing their decision to invest, work, settle and travel in that city.

The study, which is handled within the framework of all these views, focuses on Kyrenia's brand personality. This study, which aims to measure internal and external stakeholders' attitudes, namely those connected to the city towards brand city personality traits, was applied in 5 settlements in the Kyrenia region. The data obtained were analyzed through a statistical analysis package program. According to the findings obtained through frequency analyzes and general average analyzes, the personality traits of the city of Kyrenia, which is the subject of the study, are two dimensions (excitement and sophistication), four sub-dimensions (spiritedness, contemporary, class, charm) and seven items (young, contemporary/modern, independent). , up-to-date, upperclass, good-looking, attractive / charming).

\section{Brand Personality}

\section{Literature Review}

Brand personality is a concept that significantly affects the consumer's choice and shapes the relationship between the brand and the consumer. As a result of the brand's characterization, just like the people's spiritual characteristics, the consumers get some clues about the product/service. Therefore, the concept of brand personality plays a crucial role in establishing a positive relationship with the consumer and influencing consumer preferences.

Brand personality, which has an essential contribution to the brand's differentiation, is a concept based on the thesis that brands have specific characteristics, such as people and various emotions or qualifications. Brand personality can be evaluated in terms of age, economic class, and gender. It can also be associated with some characteristic features such as warm-blooded and sensitive.

Since the physical and technical features of the products are not sufficient alone in the brand creation efforts of the enterprises, the enterprises have brought the brand personality to the agenda to make the products they produce unique. Therefore, people's brand personality and personality traits are aimed to be attributed to brands, and the concept of brand personality entered the literature (Aysen, 2012: 184).

According to the definition made by Aaker (1997: 347), brand personality is the event of 'associating the set of characteristics possessed by a person with the brand.' These personality traits may consist of demographic characteristics such as gender and age and individual characteristics such as anxiety and emotionality (Aysen, 2012: 184). In a study by Lim (2013: 6), Cocacola; Its brand is charismatic and American, and Pepsi is; It has been associated with personality traits such as young, exciting, and modern. There may be relationships between personality traits attributed to similar brands and the purchasing behavior of consumers (Çalışkur, 2014: 61) because consumers prefer brands and products that can reflect their own or ideal personalities (Özer and Ersoy, 2012: 
173). This situation reveals the importance of the concept of brand personality within the brand. At this point, the situation that reveals the importance of brand personality is the meaning that the consumer attributes to that brand and the symbolic benefit obtained from that brand, rather than the functional benefit provided by a particular brand. Because the consumer thinks that they can express their authentic and ideal selves with a particular brand they prefer, they can have a social identity (Wang \& Yang, 2008: 460). Therefore, brand personality is one of the most critical components of the brand concept (Yeh et al., 2010: 96).

As the communication between the consumer and the brand increases thanks to the brand personality, the trust and loyalty of the consumers towards the brand also improves. In order to become an original brand, it must be prevented from being imitated. In order to differentiate from other brands and products, marketing managers have to create an evident brand personality (Dölarslan, 2012: 2). In order to increase the demand for the brand, it is necessary to establish a link between the brand and the consumer. Brand personality, which is one of the most effective ways of establishing this bond, can make it possible to influence the perceptions and attitudes of consumers in the desired direction by making the brand unique (Özçelik and Torlak, 2011: 363). It has been determined in previous studies that brand personality positively affects consumer emotions (Choi et al., 2017), consumer satisfaction (Kim et al., 2015), and behavioral intentions (Ekinci \& Hosany, 2006; Ekinci et al., 2007; Usakli \& Baloglu, 2011).

According to Aaker, brand personality is the placement of humanitarian characters associated with the brand (Aaker, 1997). Brand personality, which has specific behavioral patterns like people and includes functional and emotional characteristics, establishes a connection between the brand and the customer. Brand personality can carry human characteristics such as enthusiasm, honesty, creativity, bravery, toughness, and intelligence. For example, Apple is creative, Malboro is tough, Levi's is enthusiastic. People tend to symbolize abstract entities such as brands with human characters. Therefore, every brand has an image and must have a particular personality that carries this image. Aaker states that as a result of his research, customers perceive brands according to five personality dimensions (Aaker, 1997):

- $\quad$ Sincerity (realistic, honest, dignified, smiling face)

- $\quad$ Excitement (bold, witty, imaginative, modern)

- $\quad$ Mastery (reliable, intelligent, successful)

- Intellectual (upper class, attractive)

- $\quad$ Durability (strong, durable)

Brand personality; It is a bond formed between the brand and the consumer and a feature that the consumer can easily define and express a brand. Brand personality consists of a combination of symbolic values and operational support. The symbolic values of the brand are the intrinsic, abstract product features, i.e., difference, freedom, comfort, and so on. While defining its properties, functional values define the external concrete product properties, namely longevity, durability, and quality. Every brand has a personality and character. From the general atmosphere in the commercials to the casting, the songs or lyrics used in the advertisement and many other things contribute to forming the brand personality. One of the most common features of a successful brand is its impressive personality (Çavuşoğlu, 2011: 5). Brand personality is a fundamental concept for the brand to be recognized by more consumers. The more the consumer knows the brand, the stronger the brand. The more efficiently the consumer remembers the brand, knows the features, and purchases it, the higher the level of recognition of the brand is (Ural, 2009: 21).

Countries, regions, or cities have certain personality traits, just like brands. As a result of personality traits, geographical places are perceiving as people. For example, Europe is known as "traditional and complex," Paris is "romantic." Although the personality of geographical places is symbolic, it appears as the emotional element of the image dimension (Kurtuluş, 2019). Cities' personality is formed when current and potential visitors come into direct or indirect contact with the area. Local people living in that city, working in touristic businesses, the attractions of the city and the visitors' minds about the region. Thoughts formed directly affect the formation of 
personality (Tiğl1, 2018). In addition, the city's marketing and promotion activities, image, and price indirectly affect the character. The brand personality created affects the behavior and thoughts of current and potential visitors and investors towards the region (Artuğer \& Çetinsöz, 2016). Contribute to investors' development of trust and loyalty to the area with an intense personality visitor provides. In addition, brand personality helps to differentiate (Özden, 2017).

\section{Cyprus and Kyrenia Cyprus}

The island of Cyprus is rumored to be named after a flower called 'henna flower'; It is the thirdlargest island in the Mediterranean after Sicily and Sardinia. Due to its unique location in the Eastern Mediterranean, the island of Cyprus has attracted the attention of states or civilizations that wanted to dominate the Mediterranean and Mediterranean trade throughout history. Because of this feature, the island has been called by many names throughout history until it got its current name. In Egyptian and Hittite sources, the island was named Alaska (Alasya, Alashia) or Hetim (Hettim) during the reign of the Rebel Phoenicians, and Yatnana or Ya in the Assyrian documents. In some periods, the city-states of Amatusya, Salaminya, and Pafia established in Cyprus were also used as the island's names. It is also rumored that the name Cyprus comes from the name of Kipris, which was given to the queen Cybele on the island of Cyprus, from the word copper, which is the Hebrew word for copper, or from the word cuprum, which is the equivalent of Akkadian and Latin, or Cypress, the Latin word for cypress trees found in Cyprus.

Cyprus was ruled as an independent kingdom in historical times. Later, due to its strategic location in the Mediterranean, it was patronized and invaded by powerful states. Thus, every state that dominates Cyprus has enriched the island's culture by leaving a mark on the island of Cyprus. Cyprus island, Egypt, Hittite, Greek Colonies (Aka and Dor), Phoenician, Assyria, Persia, Alexander the Great, Rome, Eastern Rome (Byzantine), Islamic State, Isaac Comnenus, British, Templier Knights, Lusignan, Venice, Ottoman And it fell under the auspices or domination of the British states.

Due to its dominant position in the Mediterranean, its military and commercial importance, the island of Cyprus has been a battleground between Muslims and Christians who wanted to dominate the Mediterranean for centuries.

In 1960, the Republic of Cyprus was established as a bi-national state based on the partnership of Turkish Cypriots and Greek Cypriots. However, the 1960 Partnership Republic lasted only three short years. As a result, since 1963, there is no joint central administration on the island that would represent the whole of Cyprus.

Due to the politically based problems between Greek Cypriots and Turkish Cypriots, the Greek Cypriot community (Southern Cyprus) settled in the south of the island, and the Turkish Cypriot community (Northern Cyprus) settled in the north of the island with an agreement implemented through the UN Peacekeeping Force in 1975. Happened. These two sections are separated by an 'intermediate zone that stretches for $180 \mathrm{~km}$ and varies in width from 5 meters to 7 $\mathrm{km}$. In 1983, Northern Cyprus declared its independence, and it was known that the two peoples in Cyprus were destined to live side by side and that a peaceful, fair and viable solution was found through negotiations based on equality, the reestablishment of the partnership between the two peoples on the island and the problem through diplomatic channels. It is aimed to be resolved. In line with these goals, negotiations for a solution are still ongoing between the two communities. However, a solution has not been reached yet; Northern Cyprus has been subjected to various economic and political-based isolations towards the solution of the Cyprus problem, the negotiations for a solution between the two communities continue. However, a solution has not yet been reached. The Cyprus Problem and the Approach of the European Union, Istanbul-2007, p.23.Ozarslan, p.23-24; Çevikel, Nuri; Cyprus State 1750-1800, Famagusta, KKTC2000, p. 1-10.)

\section{Kyrenia}

Girne, one of the most beautiful and mysterious cities in the Mediterranean, is located on the northern coast of Cyprus Island on the narrow coastline between the Beşparmak Mountains and the 
sea. While Kyrenia is fascinated by its location, natural beauties, and history, it is the city with the highest tourist facilities. Just behind the city, located by the sea, there is a strait that provides passage from the Girne Row Mountains to the inner parts of the island.

Harbor is one of the most beautiful places and symbol of the Kyrenia region, where old buildings are preserved; It is in the shape of a horseshoe. Old Venetian, Ottoman, and British Colonial Period buildings, small hotels, bars, and restaurants around the harbor create a unique atmosphere for tourists. Kyrenia has a unique beauty with its yachts, cute restaurants, small bars, and colorful fishing boats, especially in the summer months.

The Kyrenia region; consists of six main settlements: Girne, Lapta, Alsancak, Çatalköy, Esentepe, Dikmen, and six central local governments (TRNC, Information Office, b.t).

\section{Research Methodology}

In order to measure the brand personality of the Kyrenia region, the brand personality scale was adapted from J.L Aaker's (1997) brand personality scale to a large extent. As a result of the analysis, the brand personality scale has been gathered under five main factors. These; It is grouped as Sincerity, Excitement, Competence, Sophistication, Ruggedness.

In line with the purpose of the research, using J.L Aaker's (1997) brand personality scale, 'What are the personality traits assigned to the Kyrenia region?' In response to the question, it is aimed to measure the brand personality of the Kyrenia region. The scale used for the study was prepared using the Likert scale question type. Evaluation in the 5-Likert scale used in this study; (1) Strongly agree, (2) Agree, (3) No Idea, (4) Disagree, (5) Strongly Disagree.

Collected data; Reliability and validity analyzes were examined using frequency and general averages.

Findings obtained by the survey method were transformed into tables and interpreted. Scale; Geographically, local administrators/employees of five main settlement centers in the Kyrenia region (Girne central Lapta, Alsancak, Çatalköy and Esentepe), people living in the region and working people, private sector managers/employees, non-governmental organization managers/employees, academic and administrative staff of the universities in the region And its students and tourists. The local manager of the Dikmen district did not allow any research to be conducted. Therefore, data results were collected from only five main settlement centers.

\section{Findings}

Perceptions of the Kyrenia region's personality traits have been researched with the brand personality scale, and the average answers and standard deviation results given to the research questions are shown in Table 1.

Table 1: Average Summaries of the Responses to the Survey's Brand Personality Scale

\begin{tabular}{|l|l|l|l|l|l|}
\hline & N & Minimum & Maksimum & Ortalama & Std. Sapma \\
\hline $\begin{array}{l}\text { Q1. 1: To what extent do } \\
\text { you agree when the } \\
\text { following statements match } \\
\text { the Kyrenia city features? } \\
\text { Down-to-earth }\end{array}$ & 389 & 1 & & & \\
\hline $\begin{array}{l}\text { Q1. 2: To what extent do } \\
\text { you agree when the } \\
\text { following statements match } \\
\text { the Kyrenia city features? } \\
\text { Small }\end{array}$ & 390 & 1 & 5 & 2,62 &, 986 \\
\hline $\begin{array}{l}\text { Q1. 3: To what extent do } \\
\text { you agree when the } \\
\text { following statements match } \\
\text { the Kyrenia city features? }\end{array}$ & 387 & 1 & 5 & 2,72 &, 988 \\
Family-oriented
\end{tabular}




\begin{tabular}{|c|c|c|c|c|c|}
\hline $\begin{array}{l}\text { Q1. 4: To what extent do } \\
\text { you agree when the } \\
\text { following statements match } \\
\text { the Kyrenia city features? } \\
\text { Honest }\end{array}$ & 388 & 1 & 5 & 2,80 & ,951 \\
\hline $\begin{array}{l}\text { Q1. 5: To what extent do } \\
\text { you agree when the } \\
\text { following statements match } \\
\text { the Kyrenia city features? } \\
\text { Sincere }\end{array}$ & 383 & 1 & 5 & 2,67 & 944 \\
\hline $\begin{array}{l}\text { Q1. 6: To what extent do } \\
\text { you agree when the } \\
\text { following statements match } \\
\text { the Kyrenia city features? } \\
\text { Realistic }\end{array}$ & 387 & 1 & 5 & 2,91 & ,952 \\
\hline $\begin{array}{l}\text { Q1. 7: To what extent do } \\
\text { you agree when the } \\
\text { following statements match } \\
\text { the Kyrenia city features? } \\
\text { Virtuous / Sensitive / } \\
\text { Healthy }\end{array}$ & 389 & 1 & 5 & 2,62 & ,949 \\
\hline $\begin{array}{l}\text { Q1. 8: To what extent do } \\
\text { you agree when the } \\
\text { following statements match } \\
\text { the Kyrenia city features? } \\
\text { Original }\end{array}$ & 386 & 1 & 5 & 2,52 & ,951 \\
\hline $\begin{array}{l}\text { Q1. 9: To what extent do } \\
\text { you agree when the } \\
\text { following statements match } \\
\text { Kyrenia city's features? } \\
\text { Cheerful }\end{array}$ & 391 & 1 & 5 & 2,77 & 987 \\
\hline $\begin{array}{l}\text { Q1. 10: To what extent do } \\
\text { you agree when the } \\
\text { following statements match } \\
\text { the Kyrenia city features? } \\
\text { Friendly }\end{array}$ & 391 & 1 & 5 & 2,57 & ,936 \\
\hline $\begin{array}{l}\text { Q1. 11: To what extent do } \\
\text { you agree when the } \\
\text { following statements match } \\
\text { the Kyrenia city features? } \\
\text { Emotional }\end{array}$ & 389 & 1 & 5 & 2,75 & ,916 \\
\hline $\begin{array}{l}\text { Q1. 12: To what extent do } \\
\text { you agree when the } \\
\text { following statements match } \\
\text { the Kyrenia city features? } \\
\text { Daring }\end{array}$ & 388 & 1 & 5 & 2,55 & 1,035 \\
\hline $\begin{array}{l}\text { Q1. 13: To what extent do } \\
\text { you agree when the } \\
\text { following statements match } \\
\text { the Kyrenia city features? } \\
\text { Fashionable }\end{array}$ & 387 & 1 & 5 & 2,56 & ,965 \\
\hline $\begin{array}{l}\text { Q1. 14: To what extent do } \\
\text { you agree when the } \\
\text { following statements match } \\
\text { the Kyrenia city features? } \\
\text { Excited }\end{array}$ & 387 & 1 & 5 & 2,65 & ,924 \\
\hline
\end{tabular}




\begin{tabular}{|c|c|c|c|c|c|}
\hline $\begin{array}{l}\text { Q1. 15: To what extent do } \\
\text { you agree when the } \\
\text { following statements match } \\
\text { with Kyrenia city's } \\
\text { features? Young }\end{array}$ & 387 & 1 & 5 & 2,46 & 1,016 \\
\hline $\begin{array}{l}\text { Q1. 16: To what extent do } \\
\text { you agree when the } \\
\text { following statements match } \\
\text { the Kyrenia city features? } \\
\text { Calm }\end{array}$ & 380 & 1 & 5 & 2,50 & ,976 \\
\hline $\begin{array}{l}\text { Q1. 17: To what extent do } \\
\text { you agree when the } \\
\text { following statements match } \\
\text { the Kyrenia city features? } \\
\text { Creative / Daydreamer }\end{array}$ & 390 & 1 & 5 & 2,71 & 1,018 \\
\hline $\begin{array}{l}\text { Q1. 18: To what extent do } \\
\text { you agree when the } \\
\text { following statements match } \\
\text { Kyrenia city's features? } \\
\text { Unique }\end{array}$ & 385 & 1 & 5 & 2,77 & 1,056 \\
\hline $\begin{array}{l}\text { Q1. 19: To what extent do } \\
\text { you agree when the } \\
\text { following statements match } \\
\text { the Kyrenia city features? } \\
\text { Contemporary / Modern }\end{array}$ & 385 & 1 & 5 & 2,50 & 1,068 \\
\hline $\begin{array}{l}\text { Q1. 20: To what extent do } \\
\text { you agree when the } \\
\text { following statements match } \\
\text { the Kyrenia city features? } \\
\text { Independent }\end{array}$ & 387 & 1 & 5 & 2,50 & 1,081 \\
\hline $\begin{array}{l}\text { Q1. 21: To what extent do } \\
\text { you agree when the } \\
\text { following statements match } \\
\text { the Kyrenia city features? } \\
\text { Up-to-date }\end{array}$ & 379 & 1 & 5 & 2,47 & 1,071 \\
\hline $\begin{array}{l}\text { Q1. 22: To what extent do } \\
\text { you agree when the } \\
\text { following statements match } \\
\text { the Kyrenia city features? } \\
\text { Reliable }\end{array}$ & 385 & 1 & 5 & 2,80 & 1,065 \\
\hline $\begin{array}{l}\text { Q1. 23: To what extent do } \\
\text { you agree when the } \\
\text { following statements match } \\
\text { the Kyrenia city features? } \\
\text { Hard-working }\end{array}$ & 381 & 1 & 5 & 2,72 & 1,168 \\
\hline $\begin{array}{l}\text { Q1. 24: To what extent do } \\
\text { you agree when the } \\
\text { following statements match } \\
\text { the Kyrenia city features? } \\
\text { Intelligent }\end{array}$ & 384 & 1 & 5 & 2,60 & 957 \\
\hline $\begin{array}{l}\text { Q1. 25: To what extent do } \\
\text { you agree when the } \\
\text { following statements match } \\
\text { the Kyrenia city features? } \\
\text { Technical / Theoretical / } \\
\text { Regular }\end{array}$ & 388 & 1 & 5 & 2,96 & 1,094 \\
\hline
\end{tabular}




\begin{tabular}{|c|c|c|c|c|c|}
\hline $\begin{array}{l}\text { Q1. 26: To what extent do } \\
\text { you agree when the } \\
\text { following statements match } \\
\text { the Kyrenia city features? } \\
\text { Corporate / Collective }\end{array}$ & 384 & 1 & 5 & 2,97 & 1,082 \\
\hline $\begin{array}{l}\text { Q1. 27: To what extent do } \\
\text { you agree when the } \\
\text { following statements match } \\
\text { the Kyrenia city features? } \\
\text { Successful }\end{array}$ & 381 & 1 & 5 & 2,76 & 1,033 \\
\hline $\begin{array}{l}\text { Q1. 28: To what extent do } \\
\text { you agree when the } \\
\text { following statements match } \\
\text { the Kyrenia city features? } \\
\text { Leader }\end{array}$ & 386 & 1 & 5 & 2,85 & 1,137 \\
\hline $\begin{array}{l}\text { Q1. 29: To what extent do } \\
\text { you agree when the } \\
\text { following statements match } \\
\text { the Kyrenia city features? } \\
\text { Confident }\end{array}$ & 379 & 1 & 5 & 2,73 & 1,156 \\
\hline $\begin{array}{l}\text { Q1. 30: To what extent do } \\
\text { you agree when the } \\
\text { following statements match } \\
\text { with Kyrenia city's } \\
\text { features? Upper-class }\end{array}$ & 387 & 1 & 5 & 2,41 & 1,018 \\
\hline $\begin{array}{l}\text { Q1. 3: To what extent do } \\
\text { you agree when the } \\
\text { following statements match } \\
\text { the Kyrenia city features? } \\
\text { Good-looking }\end{array}$ & 384 & 1 & 5 & 2,46 & ,958 \\
\hline $\begin{array}{l}\text { Q1. 32: To what extent do } \\
\text { you agree when the } \\
\text { following statements match } \\
\text { the Kyrenia city features? } \\
\text { Attractive / Charming }\end{array}$ & 385 & 1 & 5 & 2,50 & 1,088 \\
\hline $\begin{array}{l}\text { Q1. 33: To what extent do } \\
\text { you agree when the } \\
\text { following statements match } \\
\text { the Kyrenia city features? } \\
\text { Feminine }\end{array}$ & 379 & 1 & 5 & 2,88 & ,973 \\
\hline $\begin{array}{l}\text { Q1. 34: To what extent do } \\
\text { you agree when the } \\
\text { following statements match } \\
\text { the Kyrenia city features? } \\
\text { Smooth }\end{array}$ & 377 & 1 & 5 & 2,94 & 970 \\
\hline $\begin{array}{l}\text { Q1. 35: To what extent do } \\
\text { you agree when the } \\
\text { following statements match } \\
\text { the Kyrenia city features? } \\
\text { Outdoorsy }\end{array}$ & 374 & 1 & 5 & 3,06 & 954 \\
\hline $\begin{array}{l}\text { Q1. 36: To what extent do } \\
\text { you agree when the } \\
\text { following statements match } \\
\text { the Kyrenia city features? } \\
\text { Masculine }\end{array}$ & 387 & 1 & 5 & 2,65 & 995, \\
\hline
\end{tabular}




\begin{tabular}{|l|l|l|l|l|l|}
\hline $\begin{array}{l}\text { Q1. 37: To what extent do } \\
\text { you agree when the } \\
\text { following statements match } \\
\text { the Kyrenia city features? } \\
\text { Western }\end{array}$ & 378 & 1 & 5 & 2,67 & 1,031 \\
\hline $\begin{array}{l}\text { Q1. 38: } \text { To what extent do } \\
\text { you agree when the } \\
\text { following statements match } \\
\text { the Kyrenia city features? } \\
\text { Tough / Difficult }\end{array}$ & 385 & 1 & 5 & 2,81 & 1,006 \\
\hline $\begin{array}{l}\text { Q1. 39: } \text { To what extent do } \\
\text { you agree when the } \\
\text { following statements match } \\
\text { the Kyrenia city features? } \\
\text { Durable / Sturdy }\end{array}$ & 385 & 1 & 5 & 2,74 &, 999 \\
\hline Valid N (listwise) & 331 & & & & \\
\hline
\end{tabular}

Table 2: Summaries of the Responses to the Questionnaire's Brand Personality Scale

\begin{tabular}{|l|l|}
\hline DIMENSIONS & ANSWERS \\
\hline SINCERITY & \\
\hline 1.1 Down-to-earth & \\
\hline Down-to-earth & no idea \\
\hline Small & no idea \\
\hline Family-oriented & no idea \\
\hline 1.2 Honesty & \\
\hline Honest & no idea \\
\hline Sincere & no idea \\
\hline Realistic & no idea \\
\hline 1.3 Wholesomeness & \\
\hline Virtuous / Sensitive / Healthy & no idea \\
\hline Original & no idea \\
\hline 1.4 Cheerfulness & \\
\hline Cheerful & no idea \\
\hline Friendly & no idea \\
\hline Emotional & no idea \\
\hline EXCITEMENT & \\
\hline 2.1 Daring & \\
\hline Daring & no idea \\
\hline Fashionable & no idea \\
\hline Excited & no idea \\
\hline $\mathbf{2 . 2}$ Spiritedness & \\
\hline Young & Agree \\
\hline Calm & no idea \\
\hline $\mathbf{2 . 3 ~ I m a g i n a t i o n ~}$ & \\
\hline Creative / Daydreamer & no idea \\
\hline Unique & no idea \\
\hline $\mathbf{2 . 4}$ Contemporary & \\
\hline Contemporary / Modern & Agree \\
\hline Independent & Agree \\
\hline & \\
\hline
\end{tabular}




\begin{tabular}{|l|l|}
\hline Up-to-date & Agree \\
\hline 3. COMPETENCE & \\
\hline 3.1 Reliability & no idea \\
\hline Reliable & no idea \\
\hline Hard-working & \\
\hline 3.2 Intelligence & no idea \\
\hline Intelligent & no idea \\
\hline Technical / Theoretical / Regular & no idea \\
\hline Corporate / Collective & \\
\hline 3.3 Success & no idea \\
\hline Successful & no idea \\
\hline Leader & no idea \\
\hline Confident & \\
\hline 4. SOPHISTICATION & \\
\hline 4.1 Class & Agree \\
\hline Upper-class & Agree \\
\hline Good-looking & \\
\hline 4.2 Charm & agree \\
\hline Attractive / Charming & no idea \\
\hline Feminine & no idea \\
\hline Smooth & \\
\hline 5. RUGGEDNESS & \\
\hline 5.1 Masculinity & no idea \\
\hline Outdoorsy & no idea \\
\hline Masculine & no idea \\
\hline Western & \\
\hline 5.2 Toughness & no idea \\
\hline Tough / Difficult & no idea \\
\hline Durable / Sturdy & \\
\hline
\end{tabular}

\section{Comments and Discussion}

As a result of the findings in Table 2, the study group in the dimension of sincerity in the Kyrenia brand personality scale; 4 sub-dimensions (grounded, honest, healthy, and cheerful) and 15 items (down-to-earth, small, family-oriented, honest, sincere, realistic, healthy/virtuous/sensitive, authentic, cheerful, friendly, emotional) The average is like I have no idea. As a personality, the working group's Kyrenia region; $\mathrm{He}$ is small, family-oriented, honest, sincere, realistic, healthy/virtuous/sensitive, original, cheerful, friendly, emotional.

Excitement-sized; The average of the responses to 2 sub-dimensions (courage and creativity) and five items (trendy, exciting, creative/imaginative, unique) I have no idea, the average of the responses to 4 items (young, contemporary/modern, independent, current) of the Vitality and Modernity sub-dimension I agree, the response given to the excellent item of the vitality sub-dimension is seen in Table 2 without any idea. The working group considers the Kyrenia region as young, contemporary/modern, independent, and up-to-date but does not see it as trendy, exciting, creative/dreamy, unique, and relaxed. The answers are given to 3 sub-dimensions (reliability, intelligence, and success), and five items (reliable, hardworking, intelligent, technical/theoretical/canonical, collective/institutional, successful, leader, and self-confident) are in the competency dimension the form of no idea. Therefore, the working group does not evaluate the Kyrenia region as reliable, intelligent, and successful in terms of competence. 
Development dimension; The responses were given to both items of the social class subdimension (wealthy class and good image). One item of the attraction sub-dimension (attractive/attractive) is seen in Table 2, as I agree. Nevertheless, the answers to the feminine and smooth item of the glamor sub-dimension are in the form of no idea. In terms of development, the working group sees the Kyrenia region positively, except for feminine and smoothness. On the other hand, seeing it as attractive and attractive may be advantageous in the correct city identity and city image to be created.

All of the responses given to the two sub-dimensions (masculinity and resilience and five items (external spatial, masculine, western, tough/challenging, robust/durable) in the strength dimension are seen in Table 2 without any idea. Since there is no clear answer to the feminine item of the development sub-dimension, we see that the working group could not fully locate the Kyrenia region related to these dimensions in their minds.

"Masculinity and femininity are distinctive personality traits. These can be transferred to the brand personality and used practically by customers who connect with the qualities and human qualities of the brand "(Grohmann 2008, pp. 1-59). Grohmann (2008) determined that the ability to organize brands according to masculinity/femininity status can be used to recognize the customer perception and positioning strategies of competing brands. "Two steps can be taken to gender a product; The first step is to design or adapt the product or brand according to the stereotypical male or female appeal. The second is to give the product or brand a gendered appearance through advertising or promotional activities strongly associated with masculine or feminine sexual roles. Advertising has the power to change widely accepted values. It can be used to change people's attitudes, even rigorous attitudes on these issues "(Cohan, 2001, pp. 323-337).

This situation represents an essential advantage in gaining a competitive identity against other competing cities (Kanıbir, Nart, \& Saydan, 2010).

\section{Conclusion and Recommendations}

First introduced by Gardner and Levy in 1955 and listed by Jennifer Aaker (1997) in 1997, the concept of 'brand personality was accepted in the literature by Aaker; It can be defined as all human character traits associated with the brand (Aaker, 1997: 347). Keller (1993) also defined brand personality as attributing human character traits to the brand, close to Aaker (1997). In this context, brand personality is based on the assumption that brands, like people, have personality traits, specific emotions, or impressions.

Brand perception does not only consist of the services offered by the enterprise/institution to its users. The perception of the brand is also influenced by the factors specific to the consumer or the user. Many topics related to brand and brand (brand loyalty, brand awareness, brand personality, etc.) have been examined in national and international literature.

With the brand concept coming to the forefront, researches on brand personality have also gained importance. Brands have a personality just like people. The group of human characteristics/adjectives associated with a brand form the brand personality (Aksoy \& Özsomer, 2007). Nowadays, in many studies, the subjects asked, 'If you assume that the brand has a personality, how would you define its personality?' They can answer the question very comfortably and efficiently. Creating a brand personality and building a brand are essential for brand management (Azoulay and Kapferer 2003).

In this study carried out in this context, it was tried to determine how the brand personality is perceived by the internal and external stakeholders of the Kyrenia region.

When the personality traits of the Kyrenia region are examined; It is understood that the city is defined as young, contemporary/modern, independent, up-to-date, upper-class, goodlooking, and attractive/charming.

As a result, the perceptions of the internal and external stakeholders of the city towards the city, their attitudes towards that city as a result of these perceptions, and the determination of their positive or negative satisfaction, as a result, are essential to the public, private sector, and non- 
governmental organizations in terms of creating and developing strategies, plans, and policies for the branding of the city. Therefore, it will provide a guide and advice.

Today, when trade wars are experience intensely, it is known that both businesses, cities, and states attach importance to branding efforts to be victorious from these wars. The brand phenomenon that companies, cities, and states want to differentiate themselves and make them valuable in the eyes of consumers, thus gaining strategic advantage in trade wars, consists of many variables. One of these variables is personality (Yaraşl1, 2017). Light of these results obtained from the research, the perceptions of the internal and external stakeholders of the city of Kyrenia towards the city can develop positively, considering which features of the town of Kyrenia are highlighted and set in terms of brand personality characteristics and which parts are completed and improved. Branding a region, city, or destination is mainly within the country's interest, regional city managers, and leaders of key sectors. Municipalities are at the forefront of the most relevant authorities or practitioners regarding the brand management of a city. Because they are more involved in the application, come from within the town's people, and know the city better, the mayors as the brand manager of the city and the central governments in coordination are the first ones that come to mind. The brand personality traits of the town of Kyrenia, which emerged as a result of this research; because it is a big "picture" that shows the city's many aspects, potential, weaknesses, and opportunities. Analysis results thinking that it may be possible to get general ideas about the various dimensions of the problem or solution, especially by looking at the picture revealed for the local governments of the Kyrenia region. However, it seems necessary for the practitioners to elaborate the general image of the city presented by this research and similar studies with further studies and to implement them by the project.

\section{Research Limitation and Directions for Future Studies}

There are some limitations of the study. Geographically, it is limited to five of the six main settlements (Lapta, Alsancak, Girne centre, Çatalköy, Esentepe and Dikmen) in the Kyrenia region (Girne center Lapta, Alsancak, Çatalköy and Esentepe). It is also limited to the local administrators/employees of the five main settlements in the Kyrenia region, the people living and working in the area, private sector managers/employees, non-governmental organization managers/employees, academic, administrative, and students of the universities in the region and tourists. The research was applied on 450 people around the Kyrenia region in November and December 2017. The data results were analysed over 394 valid questionnaires as 56 questionnaires were not replied, and were wrong or incomplete. Therefore, the results of the study should be used cautiously. Due to the characteristics of the research, the most critical constraints are time and money.

However, based on the study, the reseacher took liberty to include some directions fort he future studies. This study deals with the place that can examine the subject of measuring the brand personality of places and geographical areas, in general, has been a 'city. Cities are the most critical indicator of economic development in history. What kind of a brand strategy can be created for the city of Kyrenia, where we maintain our economic, political and social life, which constitutes our daily life, and it is suggested to be examined in many aspects to determine the elements that need improvement, the features that should be the highlight and the qualities that what should possess in the branding process. In future research; It is recommended to carry out detailed studies to identify all city marketing strategies and city brand development catalysts and drivers required for branding the city of Kyrenia. 


\section{References}

Aaker, J. L. (1997). Dimensions of Brand Personality. Journal of Marketing Research, 34(3), 347356.

Ahmad, M.F.,Abdullah B.Z., Tamam B.,E.,Bolong, J. (2013). Determinant Attributes of City Brand Personality That Influence Strategic Communication. Canadian Social Science, 9(2) $34-41$.

Aksoy, A. (2005). Yeni Reklamcılık, İstanbul Bilgi Üniversitesi Yayınları, İstanbul.

Aksoy, Lerzan and Ayşegül Özsomer (2007) “Türkiye'de Marka Kişiliği Oluşturan Boyutlar,” 12. Ulusal Pazarlama Kongresi Bildiriler Kitabı, Sakarya Üniversitesi, 1-14.

Artuğer, Savaş and Çetinsöz, Burçin, Cevdet. (2016). Destinasyon İmajı İle Destinasyon Kişiliği Arasındaki İlişkiyi Belirlemeye Yönelik Bir Araştırma. İşletme Araştırmaları Dergisi, 6(1), 366-384.

Aysen, E., Yaylı, A. and Helvacı, E. (2012). Üniversitelerin Marka Kişiliği Algısının Belirlenmesi Üzerine Bir Araştırma, İşletme Araştırmaları Dergisi, 4 (4), 182-204.

Azoulay, Audrey ve Jean-Noel Kapferer (2003), "Do Brand Personality Scales Really Measure Brand Personality?," Brand Management, 11(2): 143-155.

Birtenadacogr. (b.t), 30.06.2020, http://users.metu.edu.tr/birten/adacogr.html.

Choi, Y. G., Ok, C. ve Hyun, S. S. (2017). Relationships between Brand Experiences, Personality Traits, Prestige, Relationship Quality, and Loyalty: An empirical analysis of coffeehouse brands. International Journal of Contemporary Hospitality Management, 29(4), 11851202.

Çalışkur, Ayşem (2014). Tüketicilerin Dayanıklı Tüketim Maddesi Satın Alma Değer Boyutları ve Tüketicilerin Çalışma ve Öğrenci Olma Durumları Üzerine Bir Araştırma. EKEV Akademi Dergisi, 18 (60), 55-62.

Çevikel Nuri; Kıbrıs Eyaleti 1750-1800, Gazimağusa, KKTC-2000.

Cohan, J.A. (2001). Towards a New Paradigm in the Ethics of Women's Advertising. Journal of Business Ethics. 33(4).

Dölarslan, E. Şahin. (2012). Bir Marka Kişiliği Ölçeği Değerlendirmesi, Ankara Üniversitesi SBF Dergisi, 67(2), 1-28.

Ekinci, Y. and Hosany, S. (2006). Destination Personality: An Application of Brand Personality to Tourism Destinations, Journal of Travel Research, 45, 127-139.

Gelibolu L.,Kanıbir H., Saydan R., Tutar H. ve Yavuz M.C. (2014). Kars Alg1sı İmaj ve Marka Kimliği Araştırması. Serhat Kalkınma Ajansı, Kars.

Grant, J. (2006). Markaların İnovasyon manifestosu, çev: Aytül Özer, Mediacat, İstanbul.

Grohmann, B. (2008). Gender Dimensions of Brand Personality. Journal of Marketing Research, vol. XLV.

Kanıbir, H., Nart, S. and Saydan, R. (2010). Şehir Pazarlamasında Marka Kişiliğinin Etkisi: Algılanan Marka Kişiliği - Turistlerin Tavsiye Etme Davranışı İlişkisi. Pazarlama ve Pazarlama Araştırmaları Dergisi, Sayı: 06.

Kim, J. W., Lee, F. and Suh, Y. G. (2015). Satisfaction and Loyalty from Shopping Mall Experience and Brand Personality. Services Marketing Quarterly, 36(1), 62-76.

Keller, K. L. (1993). Conseptualizing, Measuring, and Managing Customer-Based Brand Equity. Journal of Marketing, 57, 1-22.

KKTC, Enformasyon Dairesi. (b.t.), 15.07.2020, http://pio.mfa.gov.ct.tr/kibrisin-sosyal-ekonomikve-siyasi-tarihi.

Kurtuluş, Dündar. (2019). Ülkelerin Marka Kişiliği Üzerine Bir Araştırma. Atatürk Üniversitesi İktisadi ve İdari Bilimler Dergisi, 25(2), 285-300.

Lim, Seonghwan. (2013). The Effect of Destination Personality and SelfDestination Congruity on Visitors' Intentions. Master of Science, the Office of Graduate Studies of Texas A\&M University, Texas US.

Özarslan, Bahadır Bumin (2007). Uluslararası Hukuk Açısından Kıbrıs Sorunu, İstanbul, IQ Kültür Sanat Yay. 
Özçelik, Duygu Güngör, Torlak, Ömer. (2011). Marka Kişiliği Algısı ile Etnosentrik Eğilimler Arasındaki İlişki: LEVIS Ve MAVİ JEANS Üzerine Bir Uygulama. Ege Akademik Bakış, 11(3), 361-377.

Özden A., T. (2017). Şehir markalaşması ve Samsun örneği. Yüksek Lisans Tezi, Ondokuzmayıs Üniversitesi, Sosyal Bilimler Enstitüsü, Samsun.

Özer, Selda Uca, Ersoy, E. G. Kayaalp. (2012). Türkiye'de Faaliyet Gösteren Havayolu Şirketlerinin Marka Kişiliklerini Belirlemeye Yönelik Bir Araştırma. Anatolia: Turizm Araştırmaları Dergisi, 23 (2), 173 - 186.

Taşkın, Ç. \& Akat, Ö. (2008). Marka ve marka stratejileri. Alfa Aktüel yayınları, Bursa.

Tığlı, M. (2018). Marka Kişiliği. Öneri Dergisi, 5(20): 67-72.

Ural T., Markalamada Yol Haritası, Nobel Yayın Dağıtım, Ankara, 1. Baskı, Ocak 2009.

Usakli, A. ve Baloglu, S. (2011). Brand Personality of Tourist Destinations: An Application of Self-Congruity Theory, Tourism Management, 32, 114-127.

Ustakara, F. \& Aydemir, M. (2016). Spor kulüpleri ve marka: İletişim fakültesi öğrencileri örneğinde bir araştırma. Journal of Yaşar University, 11(41), 16-29.

Wang, X. ve Yang, Z. (2008).Does Country-of-Origin Matter in the Relationship between Brand Personality and Purchase Intention in Emerging Economies? Evidence from China's Auto Industry, International Marketing Review, 25(4), 458-474.

Yaraşlı, G. Y. (2017). Destinasyon İmajı ve Trabzon Yöresine Dönük Bir Çalışma. Yüksek Lisans Tezi, Başkent Üniversitesi Sosyal Bilimler Enstitüsü, Ankara.

Yeh, P-H, Liu, C-R. ve Yeh, S-S. (2010). Loyalty and Its Relationship with Travel Motivation, Brand Personality, and Congruity of Self Image, International Journal of Agricultural Travel and Tourism, 1(1), 94-106. 